\title{
Studies on Indonesian-style Experimental Dried Beef
}

\author{
Tsutomu Yasui ${ }^{*}$, Priyo Binotoro*, Takao Nagahashi, ${ }^{* *}$ \\ and Jun-ichiro Morita** \\ * Department of Animal Science \\ ** Experimental Farm, Faculty of Agriculture, Hokkaido University, \\ Sapporo 060
}

\begin{abstract}
An Indonesian-style dried beef was prepared experimentally and changes in physical and chemical properties of the product during processing were studied. The moisture content of beef decreased to about $20 \%$ by weight after drying at $40^{\circ}, 50^{\circ}$, and $60^{\circ} \mathrm{C}$ for 12,9 , and $6 \mathrm{~h}$, respectively. The water activity after drying at $40^{\circ} \mathrm{C}$ for $12 \mathrm{~h}$ was about 0.6 and the hardness of the beef dried at $40^{\circ} \mathrm{C}$ for $12 \mathrm{~h}$ was about $2 / 3$ of that dried for $24 \mathrm{~h}$. The addition of $200 \mathrm{ppm}$ of $\mathrm{NaNO}_{2}$ to the soaking solution gave a significant positive effect on the redness of the dried beef $(p<0.01)$. The redness was developed well by drying at $40^{\circ} \mathrm{C}$ for $12 \mathrm{~h}$. Residual nitrite content in beef dried at $40^{\circ} \mathrm{C}$ for $12 \mathrm{~h}$ decreased to about $30 \%$ of that added to the soaking solution. The moisture content, water activity, hardness, and redness of experimental dried beef containing $20 \%$ moisture were reversible when samples were kept under $100 \%$ humidity for $48 \mathrm{~h}$. There were not appreciable differences in main myofibrillar proteins during preparation. These results are suggestive for developing new dried meat products.
\end{abstract}

Probably the earliest method of preserving meat was drying in the wind and sun. Lowering the moisture content (dehydration) to prevent foods from spoilage is a well-known method. Such dried meat products are known as biltong in South Africa, charqui (jerky) in South America, carne secca in Brazil, pemmican in North America, tassajo in Uruguay, and dendeng in Indonesia ${ }^{1) \sim 31}$.

Dendeng may be prepared from beef, chicken, pork, or goat meat, but dried beef, dendeng sapi, is the most commonly found in Indonesia. Briefly, the preparation of the dendeng sapi is as follows: Beef is sliced lengthwise along muscle fibers to about $2 \mathrm{~mm}$ in thickness and then soaked for 1 to $6 \mathrm{~h}$ in a soaking solution containing palm sugar, cooking salt, and additives such as coriander, caraway seeds, garlic, onion, nitrate and nitrite, cane suger, or dried cassava. The proportion of ingredients used is variable but the sugar content in the products is about $40-50 \%$. The treated meat slices are then dried under sunlight.
Recently, unrefrigerated meat products gained interest in some parts of European countries since they save energy and costs during distribution and storage. Thus unrefrigerated meat products, especially traditional products, such as dendeng deserve to be studied in detail. Generally, dried foods will absorb moisture when these are kept in an environment with high humidity. Studies on the transfer of moisture from the surroundings to dried meat products are important for storage or quality control of the products. In this work, we prepared the Indonesian-style dried beef and studied the changes in moisture content, water activity, hardness, and changes in myofibrillar proteins during drying (or humidifying), and the effect of nitrites on the properties of the product.

\section{Materials and Methods}

\section{Materials}

The frozen beef was purchased from some markets or sampled at The Experimental Farm 
of Hokkaido University.

Methods

Preparation of experimental dried Beef : A cut of top rump or top side beef was used. The beef was cut into slices about $2 \mathrm{~mm}$ in thickness along muscle fibers after removing the fat. The sliced beef was soaked in a solution containing $30 \%(\mathrm{w} / \mathrm{w})$ suger, $5 \%$ (w/w) cooking salt, and $\mathrm{NaNO}_{2}$ at $4^{\circ} \mathrm{C}$ for 2 days. The weight of the soaking solution, which was boiled and cooled immediately before use, was the same as that of the sliced beef. The soaked beef was then dried in an oven with an air blower at selected temperatures.

Humidifying of experimental dried beef : A container with $100 \%$ humidity was used for humidifying. Samples dried at $40^{\circ} \mathrm{C}$ for $12 \mathrm{~h}$ were kept in the container at room temperature.

Measurement of nitrite content: Sample were cut to about $1 \mathrm{~mm}^{3}$ and homogenized by a blender at $10000 \mathrm{rpm}$ for $45 \mathrm{~s}$ to extract nitrite residues. Concentration of nitrite was measured colorimetrically by the AOAC method ${ }^{4)}$ with slight modifications as suggested by HARADA ${ }^{5)}$.

Color measurements: The color of experimental dried beef was measured as described by HUNTER $^{6)}$ with a color difference meter, Nippon Denshoku Kogyo Z-1001 DP. The surface color of several different samples was measured and color parameters were calculated by the L.a.b color system.

Water activity $\left(a_{w}\right)$ : The water activity of each sample was measured by the method of Troller et $a l .{ }^{7)}$ with a Rotronic Hygroscope, model DT.

Measurement of hardness: The hardness of experimental dried beef was measured as the force to perforate the sample by a shear-force meter, Dynagraph DYN-1250 of IIO Electric Co., Ltd. A blunt needle $1.5 \mathrm{~mm}$ in diameter was used as a perforate device.

SDS-polyacrylamide gel electrophoresis of myofibrillar proteins: Dried beef sample was homogenized with $0.1 \mathrm{M} \mathrm{KCl,} 5 \mathrm{mM}$ EDTA, and $39 \mathrm{mM}$ borate buffer $(\mathrm{pH} 7.1)$ at $4^{\circ} \mathrm{C}$.
Myofibrils were obtained as a sediment after repeated suspension and centrifugation as described by PERry and Corsi ${ }^{8}$. Polyacrylamide slab gel electrophoresis with sodium dodecyl sulfate (SDS) was done by the method of LAEMMLI $^{9)}$ and WEEDS ${ }^{10)}$. The samples $(2 \mathrm{mg} /$ $\mathrm{m} l$ ) were boiled for $5 \mathrm{~min}$ in the presence of 2 $\%(\mathrm{w} / \mathrm{v})$ SDS, 20\% (v/v) glycerol, $0.004 \%$ $(\mathrm{w} / \mathrm{v})$ bromophenol blue, 5\% (v/v) 2-mercaptoethanol, and $0.0625 \mathrm{M}$ Tris- $\mathrm{HCl}$ ( $\mathrm{pH} 6.8$ ). The final concentrations in the separation gel were $10 \% \quad(\mathrm{w} / \mathrm{v})$ acrylamide, $0.1 \% \quad(\mathrm{w} / \mathrm{v})$ SDS, $0.2 \%(\mathrm{v} / \mathrm{v})$ tetramethylethylenediamine (TEMED), $0.08 \%(\mathrm{w} / \mathrm{v})$ peroxydisulfate, and $0.1 \mathrm{M}$ Tris-Bicine ( $\mathrm{pH} 8.2$ ) and those in the stacking gel were $4 \%(\mathrm{w} / \mathrm{v})$ acrylamide, $1 \%$ $(\mathrm{w} / \mathrm{v})$ SDS, $0.15 \%(\mathrm{v} / \mathrm{v})$ TEMED, $0.08 \%(\mathrm{w} / \mathrm{v})$ peroxydisulfate, and $0.125 \mathrm{M}$ Tris- $\mathrm{HCl}(\mathrm{pH}$ 6.8). The electrode buffer contained $0.1 \mathrm{M}$ Tris-Bicine ( $\mathrm{pH} 8.2)$ and $0.1 \%(\mathrm{w} / \mathrm{v})$ SDS.

\section{Results}

\section{Drying characteristics}

Table 1 shows the thickness and weight of beef at various stages of drying. The thickness and weight of samples dried at $40^{\circ} \mathrm{C}$ for $12 \mathrm{~h}$ decreased to about $80 \%$ and $65 \%$ of those of the control beef, respectively. Fig. 1 shows the changes of moisture content of beef during drying at $40^{\circ}, 50^{\circ}$ and $60^{\circ} \mathrm{C}$. The decreasing rate of moisture content was high till $6 \mathrm{~h}$ and then became low until $12 \mathrm{~h}$. The degree of dryness was the almost constant after $12 \mathrm{~h}$. The moisture content of samples was nearly 20 $\%(\mathrm{w} / \mathrm{w})$ after drying for 12,9 , and $6 \mathrm{~h}$ at $40^{\circ}$, $50^{\circ}$, and $60^{\circ} \mathrm{C}$, respectively. When the dried beef was kept in $100 \%$ humidity, the moisture content increased to about $50 \%(\mathrm{w} / \mathrm{w})$ after $48 \mathrm{~h}$.

Changes in water activity $\left(a_{w}\right)$

The water activity of beef during drying changed from 0.97 to about 0.5 (Fig. 2). At all different temperatures used, $a_{w}$ decreased rapidly in the early drying time and then slowly. The $a_{w}$ values of the dried beef containing about $20 \%(\mathrm{w} / \mathrm{w})$ moisture were less than 0.70 . During humidifying, $a_{w}$ of the product dried at $40^{\circ}$ for $12 \mathrm{~h}$ increased from 
Table 1 Thickness and weight of experimental dried beef at each preparation stage ${ }^{\prime \prime}$

\begin{tabular}{lccc}
\hline \multicolumn{1}{c}{ Samples } & $\begin{array}{c}\text { Thickness } \\
(\mathrm{mm})\end{array}$ & $\begin{array}{c}\text { Weight } \\
(\mathscr{C})\end{array}$ \\
\hline Control beef & & $2.2 \pm 0.2$ & 100 \\
After soaking & & $2.4 \pm 0.3$ & $145.8 \pm 1$ \\
After drying at $\quad 40^{\circ} \mathrm{C}$ & & \\
& for $3 \mathrm{~h}$ & - & $72.0 \pm 4.5$ \\
& 6 & $1.9 \pm 0.3$ & $64.3 \pm 4.0$ \\
& 12 & $1.8 \pm 0.1$ & $63.7 \pm 2.3$ \\
& 18 & $1.7 \pm 0.1$ & $62.8 \pm 3.0$ \\
& 24 & $1.5 \pm 0.2$ & $51.1 \pm 3.3$ \\
\hline
\end{tabular}

1) Results are means of five experiments

\section{Humidifying time(h)}

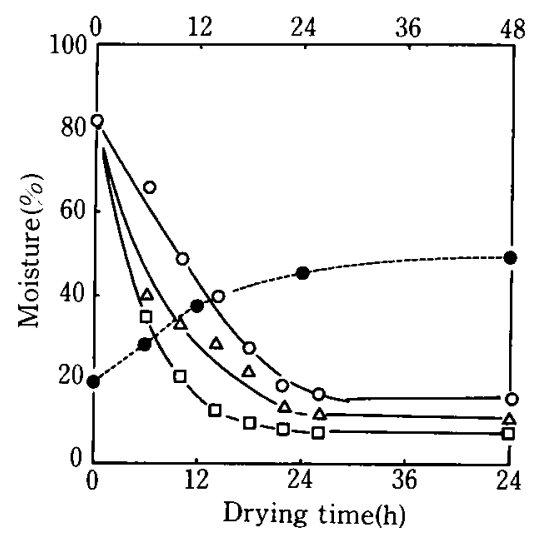

Fig. 1 Changes in moisture content of dried beef during drying and humidifying

Sample was dried at $40^{\circ} \mathrm{C}(\bigcirc), 50^{\circ} \mathrm{C}(\triangle)$, and $60^{\circ} \mathrm{C}(\square)$. Sample dried at $40^{\circ} \mathrm{C}$ for $12 \mathrm{~h}$ was humidified at room temperature under $100 \%$ humidity $(\mathbf{O})$.

0.62 to 0.88 . After humidifying for $48 \mathrm{~h}, a_{w}$ was the almost same as that of samples in the early stage of drying $(1 \sim 3 \mathrm{~h})$.

Nitrite content in dried beef

Remaining concentrations of nitrite in beef are shown in Table 2 . The concentration decreased during drying and that in a product dried at $40^{\circ} \mathrm{C}$ for $12 \mathrm{~h}$ was about $30 \%$ of that added to the soaking solution.

Changes in redness of beef

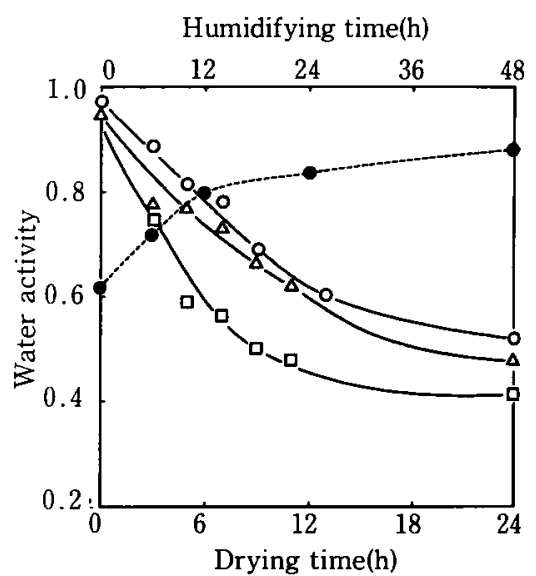

Fig. 2 Changes in water activity of dried beef during drying and humidifying

Conditions were the same as Fig. 1

Fig. 3 shows the changes of redness (a-value) of beef with or without $\mathrm{NaNO}_{2}$ during drying at $40^{\circ} \mathrm{C}$. The a-value of samples increased rapidly in early drying period and then remained at a certain value depending on the nitrite concentrations. The a-value of dried beef without $\mathrm{NaNO}_{2}$ was the smallest as expected. High a-value was found when more than $200 \mathrm{ppm}$ of $\mathrm{NaNO}_{2}$ was added to the soaking solution. Maximum redness was developed after drying for about $12 \mathrm{~h}$ in all samples. On the other hand, a-value decreased from 8.0 to 5.2 after humidifying for $48 \mathrm{~h}$ and it was the almost same as that of sample before drying. 
Table 2 Residual nitrites in experimental dried beef ${ }^{11}$

\begin{tabular}{crrrr}
\hline \multirow{2}{*}{$\begin{array}{c}\text { Added nitrites } \\
\text { to the soaking } \\
\text { solution (ppm) }\end{array}$} & \multicolumn{4}{c}{ Residual nitrites ${ }^{2)}(\mathrm{ppm})$} \\
\cline { 2 - 5 } & $6 \mathrm{~h}$ & $12 \mathrm{~h}$ & $18 \mathrm{~h}$ & $24 \mathrm{~h}$ \\
\hline 100 & $37.8 \pm 1.3$ & $32.6 \pm 1.5$ & $26.1 \pm 3.2$ & $23.9 \pm 1.1$ \\
200 & $65.6 \pm 2.2$ & $55.5 \pm 2.6$ & $46.3 \pm 1.8$ & $43.1 \pm 3.7$ \\
300 & $106.4 \pm 2.1$ & $94.6 \pm 1.4$ & $88.2 \pm 0.9$ & $65.7 \pm 1.8$ \\
500 & $182.0 \pm 2.2$ & $168.4 \pm 1.2$ & $142.4 \pm 1.3$ & $124.8 \pm 2.2$ \\
\hline
\end{tabular}

1) Dried at $40^{\circ} \mathrm{C}$

2) Calculated as $\mathrm{NaNO}_{2}$

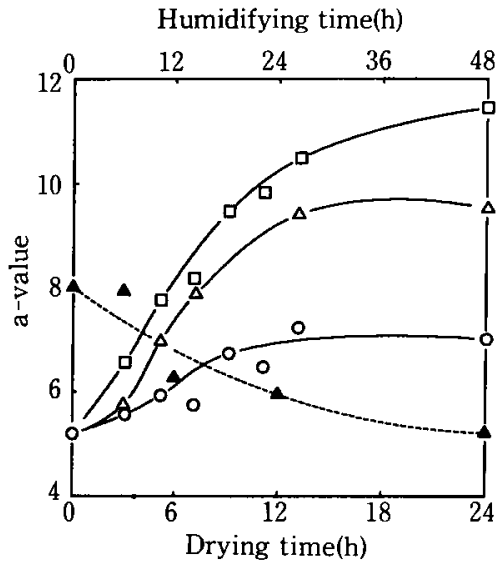

Fig. 3 Changes in a-value of dried beef during drying and humidifying

Sample was dried after soaking in a solution containing 30\% sugar, 5\% cooking salt, and $0 \mathrm{ppm}(\bigcirc), 200 \mathrm{ppm}(\triangle)$, or 300

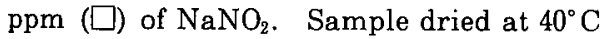
for $12 \mathrm{~h}$ after soaking in a solution containing $200 \mathrm{ppm}$ of $\mathrm{NaNO}_{2}$ was humidified at room temperature under $100 \%$ humidity (A).

Effect of nitrites on a-value (redness) of dried beef

The relationship between $\mathrm{NaNO}_{2}$ added and a-value in experimental dried beef is shown in Fig. 4. An average value of a-value did not increase by adding up to 100 ppm of $\mathrm{NaNO}_{2}$ but did increase by the addition of more than $100 \mathrm{ppm}$. The addition of more than $300 \mathrm{ppm}$ of $\mathrm{NaNO}_{2}$ failed to increase in a-value further, although a sharp increase of residual nitrite content was observed (Table 2).

Changes in hardness of beef
Fig. 5 shows the changes of hardness of beef during drying at $40^{\circ} \mathrm{C}$. The hardness increased between $6 \mathrm{~h}$ and $12 \mathrm{~h}$ of drying followed by further increase. The hardness of sample dried for $12 \mathrm{~h}$ was about $2 / 3$ of that of sample dried for $24 \mathrm{~h}$. The hardness decreased without a lag phase during early humidifying. After humidifying for $48 \mathrm{~h}$, hardness was about 0.2 $\mathrm{kg}$, which was the same as that of the beef before drying.

Changes in myofibrillar proteins during processing

Changes in myofibrillar proteins prepared from the dried beef at various stages were examined by polyacrylamide gel electrophoresis with SDS (Fig. 6). There were no wide characteristic differences in the main myofibrillar proteins among raw beef and the beef after soaking at $4^{\circ} \mathrm{C}$ for $48 \mathrm{~h}$ and drying at $40^{\circ} \mathrm{C}$ for 6 and $12 \mathrm{~h}$.

\section{Discussion}

Nitrites are commonly employed as curing agents for meat products. Sodium and potassium nitrites are used to improve the color $^{11) ~ 13)}$ and flavor of products ${ }^{12) 14) 15}$. It is also known that nitrites can inhibit the growth of Clostridium botulinum in certain cured meat products $^{12) 17)}$. However, nitrites have received negative publicity over the last several years, because they have toxic properties and because they can form nitrosamines which are known as potent carcinogens ${ }^{18) 19)}$.

The nitrite content in all samples, prepared with various concentrations of $\mathrm{NaNO}_{2}$, decreased to about $30 \%$ of that added to the soaking solution after drying at $40^{\circ} \mathrm{C}$ for $12 \mathrm{~h}$ 


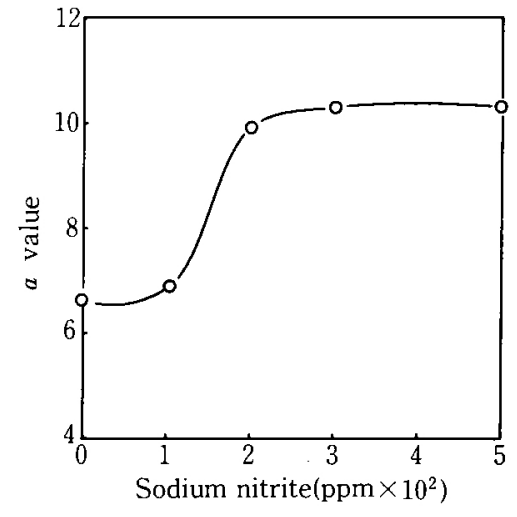

Fig. 4 Relationship between a-value of dried beef and $\mathrm{NaNO}_{2}$ concentrations in the soaking solution

Sample was dried at $40^{\circ} \mathrm{C}$ for $12 \mathrm{~h}$

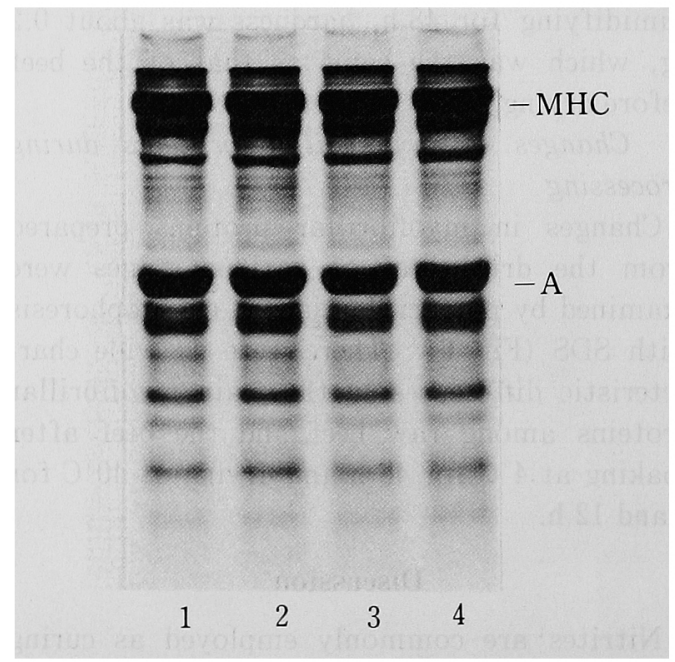

Fig. 6 SDS-polyacrylamide gel electrophoresis of myofibrillar proteins of beef

1 , raw beef; 2 , after soaking at $4^{\circ} \mathrm{C}$ for 48 $\mathrm{h} ; 3$, after drying at $40^{\circ} \mathrm{C}$ for $6 \mathrm{~h} ; 4$, after drying at $40^{\circ} \mathrm{C}$ for $12 \mathrm{~h}$. MHC, myosin heavy chain; $\mathrm{A}$, actin

as shown in Table 2. It has been established that the amount of nitrite in foods decreases considerably during processing or storage due to various mechanisms. Nitrites change by oxidation to nitric oxide and nitrate, by reduction to nitric or nitrous oxides, or by reaction

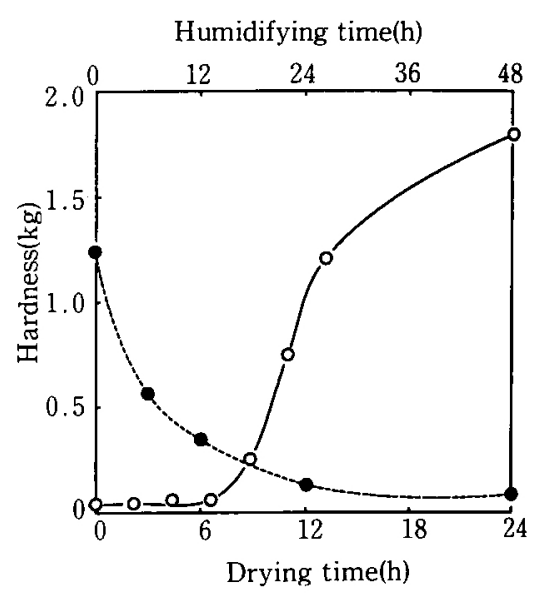

Fig. 5 Changes in hardness of dried beef during drying and humidifying

Sample was dried at $40^{\circ} \mathrm{C}$. Conditions for humidifying were the same as in Fig. 1

with phenols, amines, or thiols, etc. ${ }^{20)}$ Poulanne reported that by adding $50 \mathrm{ppm}$ of $\mathrm{NaNO}_{2}$ to dry sausage emulsions, the residual nitrite content was at the level of $10 \sim 15$ ppm. ${ }^{21)}$ On the basis of these facts, the residual nitrite content in the beef in this work is a reasonable concentration.

The experimental dried beef prepared by adding $200 \mathrm{ppm}$ of $\mathrm{NaNO}_{2}$ became appreciably redder (Fig. 3). The addition of more than $200 \mathrm{ppm}$ of $\mathrm{NaNO}_{2}$ failed to improve the color (Fig. 4). An analysis of variance was applied to differences in color with the change of treatments ${ }^{22)}$. There was no significant difference between the dried beef with $100 \mathrm{ppm}$ of $\mathrm{NaNO}_{2}$ and the control $(\mathrm{p}>0.05)$. The color became significantly redder $(p<0.01)$ than that of the controlled beef by adding $\mathrm{NaNO}_{2}$ at $200 \mathrm{ppm}$. The a-values of the experimental dried beefs with 200, 300, and $500 \mathrm{ppm}$ of $\mathrm{NaNO}_{2}$ were almost the same statistically ( $p>$ $0.05)$. The a-value increased from early drying time and then maintained a certain value. The fixed redness was reached after drying for $12 \mathrm{~h}$ (Fig. 3). This suggests that the color developed more speedily in the drying process as reported by FuJIMAKI et $a l^{23)}$ They have reported that 
nitrosomyoglobin formation accelerated mostly not in the curing period but in the cooking stage.

The $a_{w}$ values of Chinese dried meat products were in the range from 0.54 to $0.68^{24)}$. An average value of $a_{w}$ of our dried beef was 0.6 (Fig. 2). An $a_{w}$ value below 0.69 was essential for the microbiological stability of Chinese dried meat products, which contained about $4 \sim 5 \%$ salt, $20 \sim 35 \%$ sugar, and $15 \sim 20 \%$ water $^{24)}$. Our experimental dried beef prepared at $40^{\circ} \mathrm{C}$ for $12 \mathrm{~h}$ was stable microbiologically for several months when refrigerated ${ }^{25)}$.

The hardness of over-dried meat products $(24 \mathrm{~h})$ became 1.5 fold that of those products heated for $12 \mathrm{~h}$ (Fig. 5). Control of the hardness seems to be of consequence because it is an important problem in countries where dried meats are eaten without cooking. The transfer rate of moisture between foods and the surroundings is affected by physical characteristics of the food's environment ${ }^{26)}$. The moisture content of the experimental dried beef increased when the products were humidified at $100 \%$ humidity for $48 \mathrm{~h}$ (Fig. 1). These data suggest that water absorption by the dried beef can be easily forced by humidifying. Water activity (Fig. 2), a-value (Fig. 3), and hardness (Fig.5) of dried beef were reversible at.100\% humidity. The reversibility of these characteristics poses problems to be solved concerning storage conditions at various humidity levels.

Sucrose is effective in protecting myosin from denaturation due to freeze drying ${ }^{27}$ and inhibit denaturation of myosin by high or low $\mathrm{pH}$, freezing, thawing, lyophilization, or high temperature ${ }^{28)}$. NAKANO and Y ASUI ${ }^{29)}$ reported that the minimum concentration of sucrose was $0.05 \mathrm{M}$ for complete inhibition of the inactivation of myofibrillar ATPase activity due to dehydration. The changes of myofibrillar proteins prepared from beef at the various processing stages were examined by SDSpolyacrylamide gel electrophoresis. Much changes in main myofibrillar protein bands were not observed among the samples after thawing, after soaking in the curing solution, and after drying at $40^{\circ} \mathrm{C}$ for $6 \mathrm{~h}$ and $12 \mathrm{~h}$
(Fig. 6). Large amounts of sugar in the experimental dried beef protected myofibrillar proteins from denaturation prior to proteolysis.

\section{Acknowledgments}

An author, P. Bintoro, is appreciative of the Ministry of Education, Science, and Culture of Japan for financial support during this study and the Ministry of Education and Culture of Indonesia for permission of the study in Japan.

This work was supported partly by a grant from Itoh Kinen Zaidan (1986).

\section{References}

1) Sinell, H.J. and Heutschel, S. : Fleischwirtschaft, 57, 1317 (1977).

2) LEDWARD, D.A.: "Developments in meat science 2", edited by Lawrie, R. (Applied Science Pub., London), p. 159 (1981).

3) Lawrie, R.A.: "Meat Science" (4 th Ed., Pergamon Press) (1985).

4) AOAC : Official Methods of Analysis, 12 th ed., Association of Official Analytical Chemists, Washington, D.C., U.S.A.p. 422 (1975) .

5) Harada, M.: Shokuhin Eisei Kenkyu (in Japanese ), 11, 31 (1971).

6) Hunter, R.S.: "The Measurement of Appearance" (John Willey and Sons Inc., New York) (1975)

7) Troller, J.A., Bernard, D.T., and Scott, V.N. : "Compendium of Methods for the microbiological examination of foods", edited by Speck, M.L. (American Public Health Association, Washington D.C.), p. 124 (1984).

8) Perry, S.V. and Corsi, A.: Biochem. J., 68, 5 (1958)

9) LaEMmLi, U.K. : Nature (London), 277, 680 (1970).

10) WeEDS, A.G.: Eur. J. Biochem., 66, 157 (1976).

11) Siedler, A.J. and Schweigert, B.S. : Agric. Food Chem., 7, 271 (1959).

12) Ingram, M. : Fleischwirtschaft, 57, 2111 (1977).

13) Acton, J.C. and Dick, R.L. : J. Food Sci., 42, 895 (1977).

14) Cho, I.C. and Bratzler, L.J. : J. Food Sci., 35, 668 (1970). 
15) Wasserman, A.E. and Talley, F. : J. Food Sci., 37, 536 (1972).

16) Asworth, J., Hargreaves, L.L., Rosser, A. and JARvis, B.: Soc. Appl. Bacteriol. Tech. Ser., 8, 75 (1975).

17) Christiansen, L.N., TOMPKin, R.B., Shaparis, A.B., Johnston, R.W. and KantTer, D.A.: J. Food Sci., 40, 488 (1975).

18) Strich, H.F., Hornby, A.P., and Dunn, B.P. : Int. J. Cancer., 33, 625 (1984).

19) Tannenbaum, S.R., Fett, D., Young, V.R., LAND, P.D., and Bruce, W.R.: Science, 200, 1487 (1978)

20) Fox, J.B. Jr. and Nichrolas, R.A.: Agric. Food Chem., 22, 302 (1974).

21) Puolanne, E. : J. Sci. Agric. Finl., 49, 101 (1977).

22) Steel, R.G.D. and Torrie, J.H. : "Principles and Procedures of Statistics" (McGraw-Hill Int. Book Co., Tokyo) (1981).

23) Fujimaki, M., Miwa, E. and Okitani, A. : Agric. Biol. Chem., 39, 371 (1975).

24) Leistner, L.: Proc. 5 th W.C.A.P., 1, 255 (1983).

25) Bintoro, P., Morita, J., Mikawa, K. and Yasul, T. : J. Fac. Agric. Hokkaido Univ. (in preparation).

26) Van Arsdel, W.B. and Copley, M.J. : "Food Dehydration.", (Vol. 1, The Avi Publ. Co. Inc., Westport, Conecticut), p. 37 (1963).

27) Yasui, T. and Hashimoto, Y.: J. Food Sci., 31, 293 (1966).

28) Yasui, T., Morita, J., and Takahashi,
K. : J. Biochem., 60, 303 (1966)

29) Nakano, H. and Yasui, T.: Agric. Biol. Chem., 40, 107 (1976)

(Received May 13, 1987)

インドネシアースタイル乾焻牛肉に関する研究

安井 勉*・プリヨビントロ*

長橋隆雄 ${ }^{* *}$ ・森田潤一郎 ${ }^{* *}$

*北海道大学農学部畜産学科 $\overline{\mathbf{T}} 060$ 札幌市北区北 九条九丁目,

**北海道大学農学部附属農場 干060 札幌市北区北 十一条西十丁目)

インドネシア風乾燥牛肉製品を実験的に調製し, 乾燥 上程中における牛肉の物理的, 化学的性質の変化を調へ た. 牛肉の水分量は, $40,50,60^{\circ} \mathrm{C}$ におる乾燥によっ て，それぞれ $12 ， 9 ， 6$ 時間後に，およそ $20 \%$ に减少し

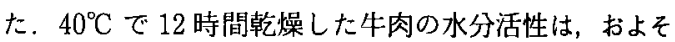
0.6 で，その時の硬さは，24時間乾燥したものの硬さの 2/3であった，浸漬液へ 200 ppm の亜硝酸ソーダを添 加すると，乾燥肉は，有意に好ましい赤色を呈した（p $<0.01) .40^{\circ} \mathrm{C}, 12$ 時間の乾燥によって, 牛肉は十分に 発色した. $40^{\circ} \mathrm{C}$ で 12 時間乾燥した時, 製品中の残留要 硝酸の量は，浸漬液へ加えた量のおよそ $30 \%$ であった， $20 \%$ の水分を含む乾燥牛肉製品の水分含量, 水分活性, 硬さ，および色は，製品を飽和水蒸気圧のむとに，室温 で 48 時間放置することによって, 乾燥前のそれらの近

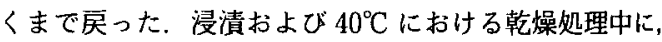
筋原䋊維蛋白質の主成分には，大きな変化が認められな かった．以上の結果は，新しい乾燥肉製品を開発するに 際して，示唆に富むむのである。 